\title{
PERSPEKTIF PENDEKATAN TAFSÎR BI AL-MA’TSÛR PASCA IBN TAYMIYYAH
}

\author{
Sahlani \\ sahlaros44@yahoo.com \\ (Fakultas Agama Islam, Universitas Muhammadiyah Tangerang)
}

\begin{abstract}
Abstrak
Ibn Taymiyyah merumuskan hierarki kualitas penafsiran Al-Qur'an yang meliputi penafsiran Al-Qur'an dengan Al-Qur'an, penafsiran Al-Qur'an dengan Sunnah Rasulullah SAW, penafsiran Al-Qur'an dengan pendapat para sahabat dan tabi'in, penafsiran Al-Qur'an dengan menggunakan pendapat para ahli bahasa dan penafsiran Al-Qur'an dengan menggunakan pendapat pribadi. Meski berada pada alternatif terakhir, Ibn Taymiyyah tidak menafikan penafsiran Al-Qur'an dengan menggunakan pendapat pribadi sebagai sesuatu yang mungkin dilakukan.
\end{abstract}

\section{Kata Kunci: Pendekatan Tafsîr Bi al-Ma'tsûr, Pasca Ibn Taymiyyah.}

\section{A. Pendahuluan}

Secara umum dapat dikemukakan bahwa penafsiran kitab suci, termasuk pula di dalamnya penafsiran Al-Qur'an, menjadi bagian penting dalam upaya mempertahankan relevansi ajaran agama terhadap perkembangan zaman. ${ }^{1}$ Perkembangan penafsiran Al-Qur'an secara historis dapat dikelompokkan ke dalam beberapa periode waktu yang pada sisi lain, menjadi tolok ukur dan ciri khas masing-masing periode bagi perbedaan metodologis dalam menafsirkan AlQur'an. Periode pertama merentang sejak masa Rasulullah saw, masa para sahabat dan masa tabi'in. Penafsiran Al-Quran pada periode pertama ini dikenal sebagai Tafsîr bi al-Ma'tsûr. ${ }^{2}$

\footnotetext{
${ }^{1}$ JMS Baljon, Modern Muslim Koran Interpretation, (Leiden: EJ. Brill, 1968), h.1-2.

${ }^{2}$ M. Quraish Shihab, Membumikan alQur'an: Fungsi dan Peran Wahyu dalam Kehidupan Masyarakat, (Bandung: Mizan, 1992), h. 71. Tafsir dengan metode ini menggunakan prinsip penafsiran ayat al-Qur'an dengan ayat alQur'an, penafsiran ayat al-Qur'an dengan pendapat Rasul, penafsiran ayat al-Qur'an dengan pendapat sahabat, dan penafsiran ayat al-Qur'an dengan pendapat Tabi'in Lihat H. Masyhud, Penafsiran Ibn
}

Periode-periode berikutnya dapat dipandang sebagai periode penerapan metode tafsir bi al-ra'y dalam menafsirkan Al-Qur'an akibat semakin derasnya proses akulturasi kaum muslimin terhadap budaya luar yang merupakan akibat langsung dari keberhasilan kaum muslimin menaklukkan dunia peradaban baru. ${ }^{3}$ Penafsiran AlQur'an di berbagai zaman telah menghasilkan beragam karya tafsir yang disusun untuk memenuhi kebutuhan zaman dan tekad agar Al-Qur'an berselaras

Taimiyyah tentang Metode Penafsiran Al-Quran Sebagai Upaya Pemurnian Pemahaman Terhadap Al-Quran, (STAIN Purwokerto: Jurnal Penelitian Agama, 2008), h.7.

${ }^{3}$ Qadhi, misalnya, menyebutkan bahwa tafsîr bi al-ra'y merupakan penafsiran yang digunakan oleh sebagian besar tokoh muslim yang berhadapan dengan budaya asing. Lihat Abu Ammar Yasir Qadhi, Introduction to the Sciences of the Quraan, hlm.329. Qadhi lebih lanjut mengemukakan bahwa dalam pendekatan tafsîr $b i$ al-ra'y, periwayatan hadis dan pendapat para sahabat tetap digunakan. Hanya saja yang lebih diutamakan adalah pemikiran kreatif (ijthad) para mufasir. Selain itu, Qadhi memasukkan beberapa bentuk tafsir lainnya seperti tafsir 'ilmi (scientific tafseer), tafsir falsafi (philosophical tafseer) dan tafsir al-isyari (sufistic tafseer) ke dalam genre tafsir bi al-ra'y. 
dengan kebutuhan dan perkembangan zaman.

Bagi Ibn Taymiyyah, ayat-ayat AlQur'an saling menjelaskan satu sama lain (yufassiru ba'dhuhu ba'dh). Inilah pendekatan tafsir yang ideal. Tetapi jika penjelasan atas suatu ayat tertentu tidak terdapat pada ayat Al-Qur'an yang lain, penafsiran atas ayat Al-Qur'an tersebut haruslah didasarkan atas Sunnah. Menurut Ibn Taymiyyah, Sunnah pada hakikatnya memiliki fungsi sebagai penjelas AlQur'an. Ibn Taymiyyah setuju terhadap pendapat Imam Syafi'i yang menyatakan bahwa apapun yang diucapkan atau dilakukan oleh Nabi saw sesungguhnya didasarkan atas pemahaman beliau terhadap Al-Qur'an. Tak seorang pun yang lebih mengenal Allah dan ajaran-Nya daripada Rasulullah saw dan dia diperintahkan Allah untuk menyampaikan pesan-Nya kepada umat manusia. ${ }^{4}$ Prinsip Ibn Taymiyyah seperti yang telah dipaparkan di atas tentu saja sangat berpengaruh terhadap pendekatan Ibn Taymiyyah dalam menafsirkan ayat-ayat Al-Qur'an.

\section{B. Pendekatan Tafsîr bi al-Ma'tsûr Pasca Ibn Taymiyyah \\ Pendekatan tafsîr bi al-ma'tsûr} banyak dianut oleh para mufasir pasca Ibn Taymiyyah. Ada beberapa karya di bidang tafsir Al-Qur'an yang berada di dalam genre pendekatan tafsîr bi al-ma'tsûr. Pertama, al-Tibyân fî̀ Aymân al-Qur'ân karya Ibn Qayyim al-Jawziyyah. Ibn Qayyim al-Jawziyyah adalah tokoh yang hidup sezaman dengan Ibn Taymiyyah dan menjadi muridnya, maka tentu karya tafsir Ibn al-Jawziyyah ini berada langsung di bawah pengaruh metode tafsir Ibn Taymiyyah. Salah satu contoh penerapan

'Ibn Taymiyyah, Majmû' al-Fatâwâ: Muqaddimah al-Tafsîr, Vol. 20, (Rabat: Maktabah Ma'arif, t.t.,), h. 136. pendekatan tafsîr bi al-ma'tsûr dalam alTibyân fî̀ Aymân al-Qur'ân karya Ibn Qayyim al-Jawziyyah ini adalah ketika Ibn Qayyim al-Jawziyyah membahas tentang kata sumpah di dalam Al-Qur'an. Ibn Qayyim al-Jawziyyah menelisik bentukbentuk kalimat sumpah di dalam AlQur'an dan berpendapat bahwa kalimat sumpah di dalam Al-Qur'an dapat berbentuk jumlah khabariyyah. Misalnya pada firman Allah Swt:

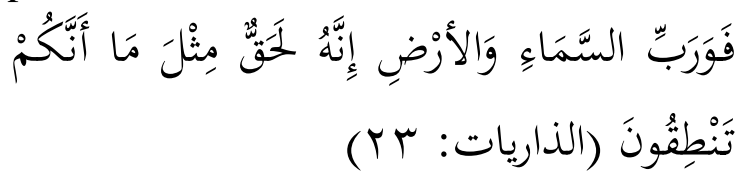

Maka demi Tuhan langit dan bumi, sesungguhnya yang dijanjikan itu adalah benar-benar (akan terjadi) seperti perkataan yang kamu ucapkan."(QS alDzariyat [51]: 23). ${ }^{5}$

Kalimat sumpah di dalam Al-Qur'an dapat berbentuk jumlah thalabiyyah. Misalnya pada firman Allah Swt:

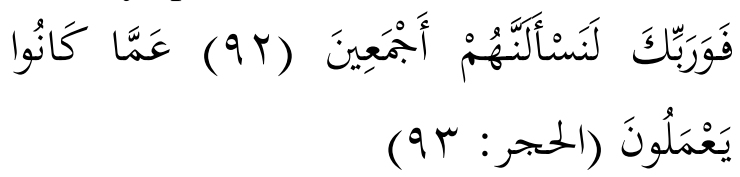

Maka demi Tuhanmu, Kami pasti akan menanyai mereka semua, tentang apa yang telah mereka kerjakan dahulu." (QS alHijr [15]: 92-93). ${ }^{6}$

Dalam konteks tafsir Ibn Qayyim alJawziyyah ini, jejak metode tafsir Ibn Taymiyyah dapat dilacak pada metode serupa yang juga digunakan oleh Ibn Qayyim al-Jawziyyah, yakni menafsirkan Al-Qur'an dengan Al-Qur'an, menafsirkan Al-Qur'an dengan Sunnah, pendapat para sahabat, kaum Salaf dan menafsirkan AlQur'n dengan pendapat ahli bahasa Arab yang tentu lebih memahami arti kata-kata dalam bahasa Arab.

\footnotetext{
${ }^{5}$ Ibn Qayyim al-Jawziyyah, al-Tibyân fî Aymân al-Qur'ân, h.5.

${ }^{6}$ Ibn Qayyim al-Jawziyyah, al-Tibyân fî Aymân al-Qur'ân, h.5.
} 
Kedua, Tafsîr al-Qur'ân al-'Azhîm karya Ibn Katsir. Metode tafsir yang digunakan oleh Ibn Katsir dalam memahami ayat-ayat Al-Qur'an adalah pendekatan tafsîr bi al-ma'tsûr, yakni menyebutkan ayat Al-Qur'an, menyebutkan arti ayat tersebut yang bersifat umum, kemudian menjelaskan penafsirannya dengan menghadirkan ayat-ayat Al-Qur'an yang lain, sabda Rasulullah saw dan atau pendapat para sahabat maupun tabi'in. Ibn Katsir juga menjelaskan langsung metode tafsir yang digunakannya dalam memahami Al-Qur'an. Ibn Katsir menyatakan bahwa jika ada orang bertanya mengenai apa metode tafsir yang paling baik? Jawabannya adalah bahwa penafsiran yang paling sahih adalah menafsirkan Al-Qur'an dengan Al-Qur'an sebab apa yang bersifat umum (mâ ujmila) pada suatu surah, dijelaskan pada surah yang lain. Jika suatu kata tidak terdapat penafsirannya dalam Al-Qur'an, Ibn Katsir menganjurkan orang untuk mencarinya di dalam Sunnah Rasulullah saw sebab Sunnah Rasulullah saw adalah penjelas bagi ayat-ayat Al-Qur'an. Jika tidak terdapat penafsiran kata itu pada Al-Qur'an maupun Sunnah, Ibn Katsir menganjurkan agar merujuk kepada pendapat para sahabat Nabi saw sebab mereka adalah orang-orang yang paling mengetahui mengenal hal itu dan menjadi saksi atas keadaan dan peristiwa yang berkaitan dengannya selain juga mereka pemahaman yang sempurna, pengetahuan yang sahih dan amal yang saleh. Jika penafsiran suatu kata dalam Al-Qur'an tidak terdapat di dalam Al-Qur'an, Sunnah atau pendapat para sahabat Nabi saw, Ibn Katsir menganjurkan agar merujuk kepada pendapat para tabi'in. ${ }^{7}$

${ }^{7}$ Ibn Katsir, Tafsîr al-Qur'ân al- 'Azhîm, vol. 2, (Riyadh: Dar Thayyibah li al-Nasyr wa alTawzî', 1999), h.8.
Contoh penafsiran Ibn Katsir yang menggunakan pendekatan tafsîr bi alma'tsûr adalah penafsiran terhadap kata al-furqân (pembeda) yang terdapat di dalam Al-Qur'an. Kata al-furqân terdapat dalam firman Allah Swt,

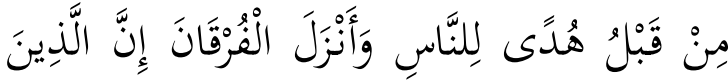

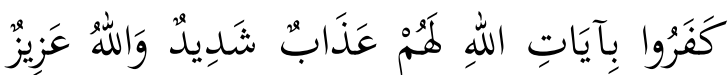

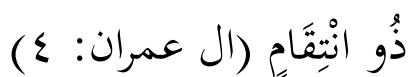

“...sebelum (Al-Qur'an), menjadi petunjuk bagi manusia, dan Dia menurunkan Al Furqan. Sesungguhnya orang-orang yang kafir terhadap ayat-ayat Allah akan memperoleh siksa yang berat; dan Allah Maha Perkasa lagi mempunyai balasan (siksa)." (QS Ali Imran [3]: 4).

Ibn Katsir menjelaskan arti kata alfurqân sebagai pembeda antara petunjuk dan kesesatan, yang benar dan yang batil, jalan yang lurus dan jalan yang menyimpang. Kemudian Ibn Katsir mengutip pendapat Qatadah dan Rabi' ibn Anas bahwa yang dimaksud dengan kata al-furqân di dalam ayat ini adalah AlQuran. Ibn Katsir juga mengutip pendapat Ibn Jarir al-Thabari bahwa kata al-furqân di dalam ayat ini berpola isim mashdar karena sebelumnya telah disebutkan AlQur'an dalam firman Allah Swt,

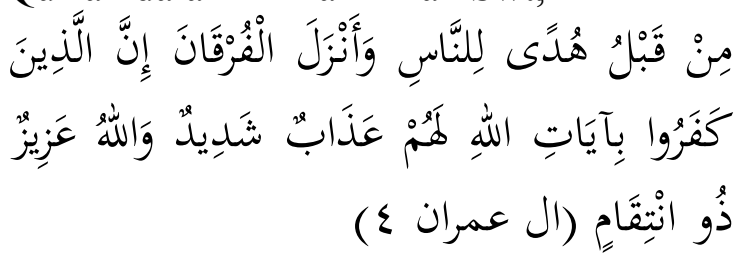

Sebelum (Al-Qur'an), menjadi petunjuk bagi manusia, dan Dia menurunkan Al Furqaan. Sesungguhnya orang-orang yang kafir terhadap ayat-ayat Allah akan memperoleh siksa yang berat; dan Allah Maha Perkasa lagi mempunyai Balasan (siksa). (QS Ali Imran [3]: 4), yakni AlQuran. $^{8}$ h. 2,6 . 
Contoh metode penafsiran Ibn Katsir yang konsisten dalam menggunakan pendekatan tafsîr bi al-ma'tsûr adalah ketika Ibn Katsir menafsirkan firman Allah SWT:

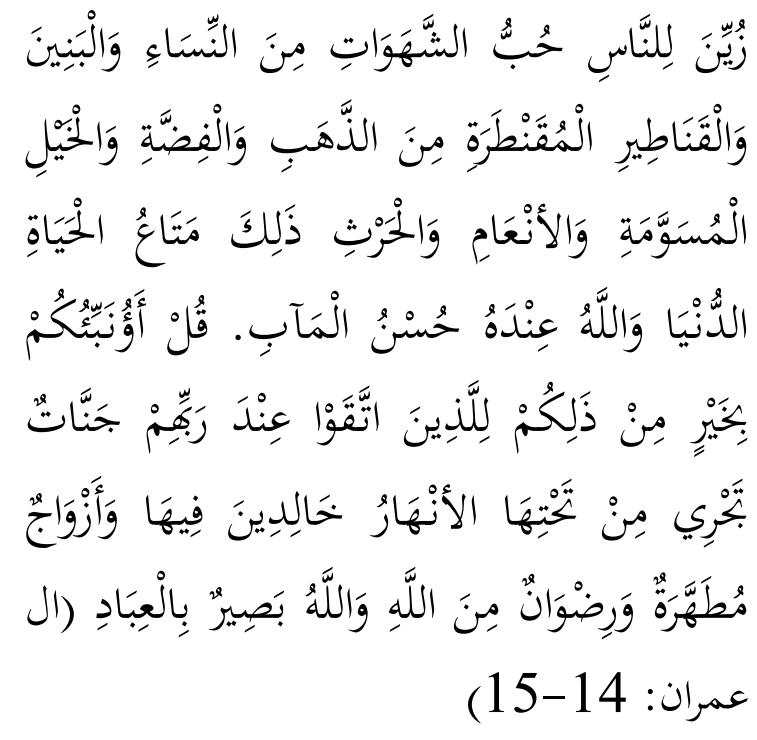

Dijadikan indah pada (pandangan) manusia kecintaan kepada apa-apa yang diingini, yaitu: wanita-wanita, anak-anak, harta yang banyak dari jenis emas, perak, kuda pilihan, binatang-binatang ternak dan sawah ladang. Itulah kesenangan hidup di dunia, dan di sisi Allah-lah tempat kembali yang baik (surga). Katakanlah: "Inginkah aku kabarkan kepadamu apa yang lebih baik dari yang demikian itu?." Untuk orang-orang yang bertakwa (kepada Allah), pada sisi Tuhan mereka ada surga yang mengalir dibawahnya sungai-sungai; mereka kekal didalamnya. Dan (mereka dikaruniai) isteri-isteri yang disucikan serta keridhaan Allah. Dan Allah Maha Melihat akan hamba-hamba-Nya." (QS Ali Imran [3]: 14-15).

Dalam menafsirkan ayat di atas, Ibn Katsir menjelaskan bahwa Allah Swt menyampaikan tentang apa yang indah di mata manusia yang meliputi kesenangan yang bersumber dari kaum perempuan dan anak-anak. Menurut Ibn Katsir, Allah SWT mengawalinya dengan menyebutkan kaum perempuan terlebih dahulu karena fitnah yang ditimbulkan oleh kaum perempuan jauh lebih besar. Dalam kaitan ini, Ibn Katsir mengutip empat hadis Nabi saw, yakni, Rasulullah saw bersabda, "Tidaklah aku tinggalkan sesudahku fitnah yang lebih berbahaya bagi lelaki selain dari kaum perempuan." Menurut Ibn Katsir, jika perempuan dipandang sebagai wasilah untuk mencegah perbuatan keji $(a l-i$ 'fâf) seperti zina atau menjadi perempuan sebagai wasilah dalam memperoleh keturunan, maka jelas hal ini merupakan sesuatu yang baik dan tidak tercela. Bahkan Ibn Katsir juga mengutip hadis yang menurutnya memperbolehkan seorang lelaki berpoligami. Hadis tersebut adalah sabda Rasulullah saw, "Sesungguhnya kebaikan umat ini adalah karena banyaknya kaum perempuan (isteri)." (HR Bukhari dalam Shahîh alBukhâri, No. 5069).

Hadis Nabi saw lainnya yang dikutip Ibn Katsir dalam menjelaskan ayat di atas adalah sabda Rasulullah saw, "Dunia itu sesuatu yang menyenangkan dan yang paling menyenangkan dari dunia adalah perempuan yang salehah. Jika (suami) menatapnya, hatinya menjadi senang. Jika (suami) memerintahkannya, dia patuh. Jika (suami) pergi meninggalkan rumah, dia mampu menjaga kehormatan dirinya dan juga hartanya." (HR Muslim dalam Shaĥhㅡ Muslim no. 1467. Al-Nasa'i dalam Sunan 6/69, dan Ibn Majah dalam Sunan no. 1855 dari hadis Abdullah ibn 'Amr ibn al-Ash ra). Rasulullah saw juga bersabda, "Aku dibuat cinta kepada kaum perempuan dan minyak wangi. Kemudian dijadikan hiburanku ada di dalam salat. (HR. Ahmad dalam Musnad 3/128, al-Nasa'i dalam Sunan, 7/61, dari hadis Anas ibn Malik. Aisyah ra berkata, "Tak ada yang lebih disukai oleh Rasulullah saw selain perempuan kecuali kuda.", 2, h. 19 .
${ }^{9}$ Ibn Katsir, Tafsîr al-Qur'ân al- 'Azhîm, vol. 
Kutipan di atas menunjukkan bahwa dalam menafsirkan Al-Qur'an, Ibn Katsir selalu menggunakan ayat Al-Qur'an, Sunnah Rasulullah saw atau perkataan para sahabat Nabi saw. Ketiga, Tafsîr alDurr al-Mantsûr fî Tafsîr bi al-Ma'tsûr karya al-Suyuthi. Karya al-Suyuthi ini jelas berada di dalam genre kitab tafsîr bi al-ma'tsûr, terlebih lagi al-Suyuthi secara eksplisit menyebutkannya dalam judul karya tafsirnya itu. Ada fenomena bahkan yang tidak lazim jika kita membaca tafsir karya al-Suyuthi ini, yakni bahwa dia bahkan memaparkan terlebih dahulu âtsâr sebelum membahas ayat-ayat Al-Qur'an tertentu. Misalnya dalam menafsirkan ayat-ayat Al-Qur'an dalam surah alFatihah. Âtsâr yang dikutip Al-Suyuthi antara lain adalah diriwayatkan dari Ibn Abu Syaybah, Abu Na'im, al-Bayhaqi, alWahidi, al-Tsa'labi dari Abu Maysarah 'Amr ibn Syurahbil bahwa Rasulullah saw berkata kepada Khadijah ra, "Sesungguhnya ketika aku menyendiri aku mendengar suara yang berseru. Demi Allah, aku sangat takut terhadap hal ini." Khadijah berkata, "Aku berlindung kepada Allah. Allah tidak akan mencelakakanmu.

Demi Allah, engkau akan mengemban amanat, menyambung silaturahmi dan benar dalam ucapan." Ketika Abubakar ra datang ke rumah Rasulullah saw dan beliau sedang tidak ada di rumah, Khadijah ra menceritakan hal ini kepadanya dan berkata, "Pergilah engkau bersama Muhammad kepada Waraqah." Ketika Rasulullah saw datang, Abu bakar langsung memegang tangan beliau seraya berkata, "Mari kita pergi menemui Waraqah." Rasulullah bertanya, "Siapa yang memberitahumu?" Abu bakar menjawab, "Khadijah." Rasulullah saw dan Abu bakar kemudian pergi menemui Waraqah dan menceritakan ihwal yang terjadi. Rasulullah bertanya, "Jika aku sedang menyendiri kemudian aku mendengar suara yang berseru, "Hai Ahmad, hai Ahmad," apakah aku lari saja?" Waraqah berkata, "Jangan lakukan itu. Jika dia datang kepadamu, tenangkan hatimu hingga engkau mendengar apa yang dikatakannya. Setelah itu datanglah kepadaku dan ceritakan kepadaku." Ketika Rasulullah saw menyendiri, ada yang berseru kepadanya, "Hai Ahmad, ucapkanlah, "Dengan menyebut nama Allah Yang Maha Pemurah lagi Maha Penyayang. Segala puji bagi Allah, Tuhan semesta alam," hingga firman Allah Swt, "...dan bukan (pula jalan) mereka yang sesat." (QS al-Fatihah [1]: 1-7). Dia berkata lagi, "Katakanlah, tidak ada tuhan selain Allah." Kemudian Rasulullah saw datang kepada Waraqah dan bercerita kepadanya. Waraqah berkata kepada Rasulullah saw, "Bergembiralah. Aku bersaksi bahwa yang menyampaikan kabar gembira kepadamu adalah yang juga menyampaikan kabar gembira kepada putera Maryam. Malaikat yang datang kepadamu adalah yang juga datang kepada Musa dan bahwa engkau adalah nabi yang diutus." 10

Sebelum membahas ayat-ayat dalam Surah al-Fatihah, al-Suyuthi juga mengutip hadis yang diriwayatkan oleh al-Bukhari, al-Darimi dalam Musnadnya, Abu Dawud, al-Turmudzi, Ibn al-Mundzir, Ibn Abi Hatim, Ibn Murdawayh dalam tafsir mereka, dari Abu Hurayrah bahwa Rasulullah saw bersabda, "Segala puji bagi Allah, Tuhan semesta alam" adalah induk Al-Qur'an dan tujuh ayat yang dibaca berulang-ulang." "Al-Suyuthi menafsirkan seluruh ayat Al-Qur'an dengan secara konsisten menggunakan pendekatan tafsîr bi al-Ma'tsûr, yakni menafsirkan Al-Qur'an dengan Al-Qur'an, dengan Sunnah Rasulullah atau dengan pendapat para sahabat maupun tabi'in.

${ }^{10}$ Al-Suyuthi, Al-Durr al-Mantsûr fî Tafsîr bi al-Ma'tsûr, (Kairo: Markaz li al-Buhuts wa alDirasat al-'Arabiyyah al-Islamiyyah, 2003), h.6.

${ }^{11}$ Al-Suyuthi, Al-Durr al-Mantsûr fî Tafsîr bi al-Ma'tsûr,h. 9. 


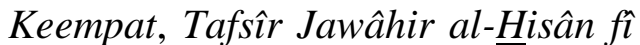
Tafsîr al-Qur'ân karya 'Abd al-Rahman ibn Muhammad ibn Makhluf Abi Zayd alTsa'alibi (786-857 $\mathrm{H})$. Pada bagian pendahuluan tafsir ini ada penjelasan mengenai kata tafsîr dan kata ta'wîl. Sebagaimana telah dikemukakan sebelumnya, definisi ta'wîl dan penerapannya dalam memahami AlQur'an telah menimbulkan polemik di kalangan ulama terdahulu (almutaqaddimîn atau salaf) dan ulama terkemudian (al-muta'akhkhirîn, khalaf). Di dalam tafsir ini dijelaskan bahwa kata ta'wîl mengandung beberapa arti. Kata ta'wîl berasal dari kata al-awl, yang artinya kembali (al-rujû́). Ibn al-Manzhur mengatakan bahwa al-awl berarti kembali (al-rujû̀). Ungkapan âla al-syay'u ya'ûl $a w l^{a n}$ wa $m a{ }^{\prime} a l^{a n}$ artinya adalah kembali (raja'a). Ungkapan awwala al-syay'a berarti mengembalikannya. Ungkapan awwala al-kalâm wa ta'awwalahu berarti menjelaskannya dan memastikannya. ${ }^{12}$

Kata ta'wîl di kalangan ulama Salaf memiliki dua arti. Pertama, menafsirkan kalimat dan menjelaskan artinya. Dengan demikian, kata ta'wîl dan kata tafsîr bersinonim. Kedua, kata ta'wîl berarti yang menjadi maksud dari suatu kata (nafs al-murâd bi al-kalâm). Jika kata itu merupakan perintah, maka ta'wilnya adalah perbuatan yang diperintahkan itu (nafs al-fi'l al-mathlûb). Jika merupakan berita (al-khabar) maka ta'wilnya adalah sesuatu yang diberitakan itu (nafs al-syay' al-mukhbar bihi aw 'alayahi). Dengan demikian, kata ta'wîl disini mengandung pengertian esensi segala sesuatu yang ada di dalam realitas (nafs al-umûr almawjûdah fì al-khârij). Dalam hal ini, kemudian dikutip pendapat Ibn Taymiyyah bahwa ta'wîl adalah bahasa Al-Qur'an yang dengannya ia diturunkan (lughah al-

\footnotetext{
${ }^{12}$ Al-Tsa'alibi, Jawâhir al- Hisân fî Tafsîr alQur'ân, (Beirut: Dar Ihya al-Turats al-Arabi, 1997), h.42.
}

qur'ân al-latî nuzila bihâ). Dengan pendapat Ibn Taymiyyah ini kemudian disebutkan bahwa ta'wîl mengandung arti mengembalikan semua yang disebutkan Al-Qur'an mengenai ta'wîl kepada arti yang kedua ini (irjâ' kulli mâ jâ'a fì alqur'ân min lafzh al-ta'wîl ilâ hâdza alma'nâ al-tsâni). Sedangkan kata ta'wil menurut pemahaman para ulama muta'akhkhirin mengandung arti memalingkan kata dari arti lahir kepada arti lain karena adanya dalil yang menghubungkannya (sharf al-lafzh 'an ma'nâ al-râjihh ilâ ma'nâ al-marjûh $l i$ dalîl $^{\text {in }}$ yaqtarinu bihi). ${ }^{13}$

Sesuai dengan genrenya sebagai tafsîr bi al-ma'tsûr, Jawâhir al-Hisân fî̀ Tafsîr al-Qur'ân karya al-Tsa'alibi juga menggunakan ayat Al-Qur'an, Sunnah Rasulullah saw dan pendapat para sahabat Nabi saw maupun tabi'in dalam menafsirkan ayat-ayat Al-Qur'an. Dalam menafsirkan surah al-Fatihah, misalnya, alTsa'alibi menempuh metode yang sama dengan metode yang digunakan oleh alSuyuthi, yakni mengutip berbagai $a t s a ̂ r$ terlebih dahulu mengenai surah al-Fatihah sebelum memulai penafsiran tentang ayatayat Al-Qur'an yang terdapat di dalam surah al-Fatihah. Sebagai contoh, alTsa'alibi mengutip pendapat Ibn Abbas bahwa surah al-Fatihah adalah sûrah Makkiyyah dan Ibn Abbas memperkuat pendapatnya dengan salah satu ayat yang terdapat di dalam surah al-Hijr, :

$$
\begin{aligned}
& \text { وَلَقَدْ آتَيْنَاكَ سَبْعًا مِنَ الْمَثَانِي وَالْقُرْآنَ الْعَظِيمَ } \\
& \text { ( }(\text { V : الحجر) }
\end{aligned}
$$

Dan sesungguhnya Kami telah berikan kepadamu tujuh ayat yang dibaca berulang-ulang dan Al-Qur'an yang agung." (QS al-Hijr [15]: 87.

Surah al-Hijr adalah surah Makkiyyah. Di dalam hadis dari Ubay ibn

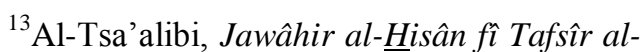
Qur'ân, h.43. 
Ka'ab disebutkan bahwa surah al-Fatihah adalah Sab'al-Matsânî (Tujuh ayat yang dibaca berulang-ulang). ${ }^{14}$ Mengenai keutamaan surah al-Fatihah, al-Tsa'alibi mengutip hadis Rasulullah saw dari Ubay ibn Ka'ab bahwa belum pernah ada surah yang diturunkan di dalam Taurat, Injil atau Al-Furqan yang serupa dengan surah alFatihah. ${ }^{15}$ Al-Tsa'alibi juga meneladani Ibn Taymiyyah dalam hal menggunakan pendapat ahli bahasa dalam menafsirkan Al-Qur'an. Misalnya dalam menafsirkan firman Allah Swt:

$$
\text { الخَمْنُ للهِهِ رَبِّ الْعَالَمِينَ (الفاتحة: } 2
$$

Segala puji bagi Allah, Tuhan semesta alam."(QS al-Fatihah [1]: 2).

Kata rabb (Tuhan) pada ayat di atas ditafsirkan oleh al-Tsa'libi dengan mengutip pendapat para ahli bahasa, yakni berarti yang disembah (al-ma'bûd), Raja Yang Maha agung (al-sayyid al-mâlik). Kata $r a b b$ secara umum berarti Tuhan segala sesuatu, yakni Allah Swt. ${ }^{16}$ Kelima, kitab tafsir Adhwa' al-Bayân fî Tafsîr alQur'ân bi al-Qur'ân karya Muhmmad Amin ibn Muhammad Mukhtar al-Jakanni al-Syanqithi (w. 1393 H). Muhammad Amin menyatakan bahwa ada dua tujuan dalam menyusun tafsir ini. Pertama, menjelaskan Al-Qur'an dengan Al-Qur'an karena ada ijmak ulama yang menyatakan bahwa jenis kitab tafsir terbaik adalah yang menafsirkan Kitab Allah dengan Kitab Allah sebab menurut Muhammad Amin, seperti halnya pula pendapat Ibn Taymiyyah, tidak ada yang lebih mengetahui arti firman Allah Swt selain Allah Swt. Kedua, menjelaskan hukumhukum fiqh yang terdapat di dalam semua ayat Al-Qur'an. Prinsip dasar Muhammad

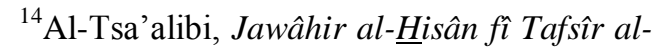
Qur'ân, h.161.

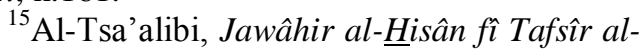
Qur'ân, h.161.

${ }^{16} \mathrm{Al}-\mathrm{Tsa}$ alibi, Jawâhir al-Hisîn fî̀ Tafsîr alQur'ân,hlm. 164.
Amin adalah menjelaskan hukum-hukum fiqh tersebut berdasarkan dalil-dalilnya dari Sunnah Rasulullah saw, dan pendapat para ulama mengenainya. Muhammad Amin menyatakan dengan tegas bahwa dia akan berpihak kepada pendapat yang kuat dan tanpa fanatisme terhadap mazhab tertentu atau terhadap pendapat dari orang tertentu. Muhammad Amin menyatakan bahwa yang menjadi perhatian utamanya adalah substansi pendapat dan bukan siapa yang berpendapat. Sebab semua pendapat mungkin saja diterima atau ditolak kecuali pendapat Rasulullah saw. selain itu, kebenaran adalah kebenaran meski orang yang mengucapkannya adalah orang yang hina. ${ }^{17}$

Selain itu, dalam menafsirkan AlQur'an, Muhammad Amin juga menjelaskan sebagian persoalan kebahasaan (al-masâ'il al-lughawiyyah) yang berkaitan dengan sharf (uraian tentang bentuk kata) atau i'râb (uraian tentang kedudukan kata) dan mengkritisi persoalan-persoalan akidah berdasarkan sanad hadis-hadis. ${ }^{18}$ Muhammad Amin juga menyatakan bahwa salah satu aspek penting dalam kitab tafsir yang disusunnya adalah menjelaskan sifat umum arti suatu kata yang diakibatkan oleh ambiguitas (alisytirâk) baik dalam kata benda (ism), kata kerja $(f i l)$ maupun huruf. Muhammad Amin kemudian menyebutkan contoh sifat umum arti yang diakibatkan oleh ambiguitas (al-isytirâk) kata benda, yakni dalam firman Allah Swt, :

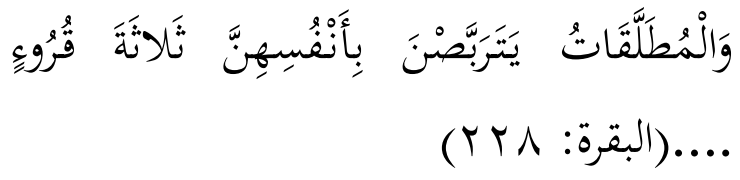

\footnotetext{
${ }^{17}$ Muhmmad Amin ibn Muhammad Mukhtar al-Jakanni al-Syanqithi, Adhwa' al-Bayân fî Tafsîr al-Qur'ân bi al-Qur'ân, (Beirut: Dar Kutub alIlmiyyah, 1996), hlm. 6-7.

${ }^{18}$ Muhmmad Amin ibn Muhammad Mukhtar al-Jakanni al-Syanqithi, Adhwa' al-Bayân fî̀ Tafsîr al-Qur'ân bi al-Qur'ân, hlm.7.
} 
“...Wanita-wanita yang ditalak handaklah menahan diri (menunggu) tiga kali quru'.." (QS. al-Baqarah [2]: 228).

Kata quru' (al-qar'u) pada ayat di atas dapat berarti masa suci dan dapat berarti pula masa haidh (menstruasi). Menurut Muhammad Amin, Allah Swt telah mengisyaratkan bahwa yang dimaksud dengan qurû' adalah masa suci sebab Allah Swt telah berfirman,:

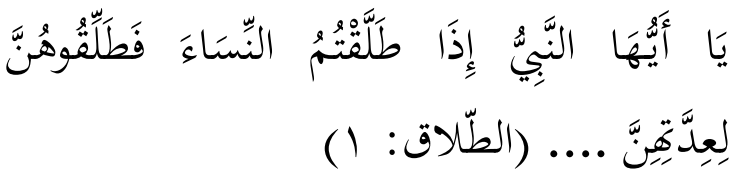

Hai Nabi, apabila kamu menceraikan isteri-isterimu maka hendaklah kamu ceraikan mereka pada waktu mereka dapat (menghadapi) iddahnya (yang wajar)..." (QS al-Thalaq [65]: 1).

Menurut Muhammad Amin, huruf lâm pada kata li 'iddatihinna menunjukkan waktu dan waktu talak yang diperintahkan di dalam ayat adalah masa suci, bukan masa haidh. Hal ini juga ditunjukkan dengan adanya tambahan huruf tô' marbûthah pada firman-Nya, "tsalâtsata qurû" sebagai bukti atas bentuk mudzakkar yang dijumlahkan, yakni masa suci (li dalâlatihâ 'alâ tadzkîr al-ma'dûd wa huwa al-athhâr). Sekiranya yang dimaksudkan adalah masa haidh, tentu bentuk kalimatnya akan menjadi tsalâtsa qurû', tanpa huruf tâ' marbûthah atau hâ'. Menurut Muhammad Amin, orang-orang Arab lazim mengatakan "tsalâtsata athhâr" dan "tsalâtsa haydhât."19 Keseluruhan penafsiran dalam Adhwa' alBayân fî Tafsîr al-Qur'ân bi al-Qur'ân karya Muhammad Amin ini memang tidak keluar dari jalur metode tafsir Ibn Taymiyyah, yakni menafsirkan Al-Qur'an dengan Al-Qur'an, dengan Sunnah Rasulullah saw, dengan pendapat para

\footnotetext{
${ }^{19}$ Muhmmad Amin ibn Muhammad Mukhtar al-Jakanni al-Syanqithi, Adhwa' al-Bayân fî̀ Tafsîr al-Qur'ân bi al-Qur'ân, hlm.9.
}

sahabat dan tabi'in serta dengan pendapat para ahli bahasa. Tujuannya tentu jelas, yakni penafsiran Al-Qur'an tidak boleh berada terlalu jauh dari ruang lingkup makna pada konteks yang berada di dalam lingkup Al-Qur'an itu diturunkan. Demikian perspektif Pendekatan Tafsîr Bi al-Ma'tsûr Pasca Ibn Taymiyyah yang diikuti dari beberapa mufasir diatas setelahnya.

\section{Penutup}

Ibn Katsir menyatakan bahwa penafsiran yang paling sahih adalah menafsirkan Al-Qur'an dengan Al-Qur'an sebab apa yang bersifat umum (mâ ujmila) pada suatu surah, dijelaskan pada surah yang lain. Jika suatu kata tidak terdapat penafsirannya dalam Al-Qur'an, Ibn Katsir menganjurkan orang untuk mencarinya di dalam Sunnah Rasulullah saw sebab Sunnah Rasulullah saw adalah penjelas bagi ayat-ayat Al-Qur'an.

Sebagaimana telah didahului oleh Ibn Taymiyyah menurutnya ketika menafsirkan harus menggunakan pendekatan tafsîr bi al-ma'tsûr, yakni pendekatan yang menafsirkan Al-Qur'an dengan Al-Qur'an, Sunnah Rasulullah SAW, pendapat para sahabat dan tabi'in, dan pendapat para ahli bahasa. Al-Qur'an yang meliputi penafsiran Al-Qur'an dengan Al-Qur'an, penafsiran Al-Qur'an dengan Sunnah Rasulullah SAW, penafsiran Al-Qur'an dengan pendapat para sahabat dan tabi'in, penafsiran AlQur'an dengan menggunakan pendapat para ahli bahasa dan penafsiran Al-Qur'an dengan menggunakan pendapat pribadi. Meski berada pada alternatif terakhir, Ibn Taymiyyah tidak menafikan penafsiran AlQur'an dengan menggunakan pendapat pribadi sebagai sesuatu yang mungkin dilakukan. 


\section{DAFTAR PUSTAKA}

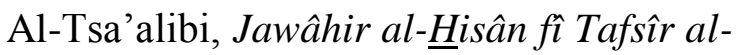
Qur'ân, (Beirut: Dar Ihya al-Turats al-Arabi, 1997)

Al-Suyuthi, Al-Durr al-Mantsûr fî Tafsîr bi al-Ma'tsûr, (Kairo: Markaz li alBuhuts wa al-Dirasat al-'Arabiyyah al-Islamiyyah, 2003),

Ahmad Gaus, Api Islam Nurcholish Madjid: Jalan Hidup Seorang Visioner. (Jakarta: PT. Kompas Media Nusantara, 2010),

Albert Hourani, The Emergence of The Modern Middle East, (California: University of California Press, 1981),

A. Hanafi, Teologi Islam, (Jakarta: Pustaka al-Husna, 1980),

G.H.A. Juyuboll, Kontroversi Hadis di Mesir (1890-1960), alih basa: Ilyas Hasan, Cet. I, (Bandung: Mizan, 1999),

Harun Nasution, Pembaharuan dalam Islam, (Jakarta: Bulan Bintang, 1975),

Harun Nasution, Pembaharuan Dalam Islam, Sejarah Pemikiran dan Gerakan, Cet. XIV. (Jakarta: Bulan Bintang, 2003),

Ibn Taymiyyah. Minhâj al-Sunnah fî Naqdh Kalâm al-Sŷ̀'ah wa alQaddariyyah, (Riyadh: Maktrabat alRiyadh al-Haditsah, tt), vol.1, 22-23. , Majmû' al-Fatâwâ: Tafsîr, Vol. 17, (Beirut: Dar al-Wafa', 2005),

Ibn Qayyim al-Jawziyyah, Al-Shawâ'iq alMursalah 'ala al-Jahmiyyah wa-alMu'aththilah, Ed. 'Ali ibn Muh"ammad al-Dakhil Allah, (Riyadh, 1412/1991-92), vol. 1, Ijtimâ' al-Juyûsy al-Islâmiyyah 'ala Ghazw al-Mu'aththilah wa-alJahmiyyah: Wa-huwa al-Risâlah alMusammâ bi al-Istiwâ'," ed. Ridwan Jami“ Ridwan (Makkah dan Riyadh, 1415/1995),
al-Tibyân fî Îmân al-Qur'ân, (Makkah: Dar Alam al-Fawa'id li alNasyr wa al-Tawzi', 1429 H), , Mukhtashar Syifâ' al-'Alîl fi Masâ'il Qadhâ' wa al-Qadar wa alHikmah wa al-Ta'lîl, ed.Khalid ibn 'Abd al-Rahman al-'Akk, (Beirut, 1996),

Ibn Katsir, Tafsîr al-Qur'ân al-'Azhîm, vol. 2, (Riyadh: Dar Thayyibah li alNasyr wa al-Tawzî', 1999),

JMS Baljon, Modern Muslim Koran Interpretation, (Leiden: EJ. Brill, 1968),

Madjid Fakhry, A History of Islamic Philosophy, (New York: Columbia Press, 2994),

Muhmmad Amin ibn Muhammad Mukhtar al-Jakanni al-Syanqithi, Adhwa' alBayân fì Tafsîr al-Qur'ân bi alQur'ân, (Beirut: Dar Kutub alIlmiyyah, 1996)

Muhammad Rasyid Ridha, Tafsîr alManâr, (Kairo: Dar al-Manar, 1947),

M. Quraish Shihab, Membumikan alQur'an: Fungsi dan Peran Wahyu dalam Kehidupan Masyarakat, (Bandung: Mizan, 1992),

Nurcholish Madjid. Islam Agama Kemanusiaan, (Jakarta: Paramadina, 1995),

Ponorogo". Disertasi Doktor Falsafah Usuluddin, (Kuala Lumpur: Akademi Pengajian Islam Universiti Malaya, 2005),

Shihâb al-D|n Ahmad Ibn Hajar al-'Asqalân|, $A l$ Durar al-Kâminah fì A'yân al-Mi'ah alTsâminah, ed. Muhammad Rashid Jad alHaqq, (Kairo, 1966-67), vol. 4 
